\title{
Groundwater Contamination Due to Nitrate in a Coastal Aquifer: Conjecture and Identification Along the West Coast from Katana to Negombo, Sri Lanka
}

\author{
P. Ratha, K. D. W. Nandalal, S. B. Weerakoon \\ Department of Civil Engineering \\ University of Peradeniya \\ Peradeniya, Sri Lanka
}

\author{
H. A. Dharmagunawardhane, H. M. T. G. A. Pitawala \\ Department of Geology \\ University of Peradeniya \\ Peradeniya, Sri Lanka
}

\begin{abstract}
Higher amount of nitrate in drinking water can cause severe methaemoglobinaemia and cancer in infants and adults. Land-uses and anthropogenic activities accompanied by hydrogeological conditions cause nitrate contamination in groundwater. This study aimed at estimating and identifying using box-plot, empirical approach and nitrate:chloride ratio $(1: 1-8: 1)$ as feasible methods to prove the possible sources in the western coastal area in Sri Lanka from Katana to Negombo. The outputs show that a high nitrate in groundwater of the area is originated mainly from on-site sanitations (i.e. soakage, pit latrine, septic tank) under denser populated settlements, while agriculture plays as a secondary source. Current groundwater nitrate levels from analyzed water wells indicated that about $30 \%$ of the water samples exceed the Maximum allowable value of $10 \mathrm{mg} / \mathrm{L} \mathrm{NO}_{3}{ }^{-}$, however, samples with nitrate greater than 50 $\mathrm{mg} / \mathrm{L}$ were not found. Denitrification processes may also contribute regulate nitrate levels in the area. Although nitrate concentration at present is not alarmingly high in the area, an increasing trend of contamination is expected with population, settlements and agriculture growth. Therefore, appropriate management and special care from relevant parties should be set up to rectify the problems and to use precious groundwater resource sustainably.
\end{abstract}

Keywords - Nitrate contamination, coastal aquifers, Sri Lanka, methaemoglobinaemia, nitrate:chloride ratio, on-site sanitations

\section{INTRODUCTION}

Coastal groundwater has become a precious resource for man in many parts of the world, where surface water is scarce. Of global use, groundwater consumption is mainly for domestic, agricultural, and industrial purposes. Groundwater needs to be free from contamination; however, pollution of groundwater is a main issue worldwide, which affects human health and economy. The restoration and remediation are not easy and may be impractical, if contaminated. Rapid urbanization, anthropogenic stresses, and climate change have been witnessing an increased pressure on groundwater pollution globally by posing diversity of threats to groundwater and consequently depleting both quality and quantity [1]. Over 30 years ago, nitrate, chloride, bacteria, and pesticide detections have been increasingly encountered. Among these pollutants, groundwater nitrate contamination has been already globally recognized as a growing problem
[2] in Europe, Asia, south Asia, and Africa. Nitrate $\left(\mathrm{NO}_{3}{ }^{-}\right)$is a main pollutant commonly found in groundwater with maximum standard limit of $50 \mathrm{mg} / \mathrm{L}$ (or $10 \mathrm{mg} / \mathrm{L}$ under natural condition as $\mathrm{NO}_{3}{ }^{-}-\mathrm{N}$ ) and of $3 \mathrm{mg} / \mathrm{L}$ for nitrite (as $\mathrm{NO}_{2}^{-}$) [3].

Nitrate contamination in groundwater is derived from different sources and processes. The origins of nitrate contamination can be natural and anthropogenic associated with four main means such as (i) human and animal waste accumulation and decomposition (point source), (ii) nitrogen fertilizer application in dense agriculture (non-point or diffuse source), (iii) earth organic matter decomposition, (iv) natural nitrate occurrence in desert area with addition of nitrate from atmosphere through rainfall $[4,5]$. Under aerobic conditions, high nitrate can be expected from a significant percentage of organic nitrogen, which will be oxidized to form nitrate (nitrification) based on biological conversion of ammonium $\left(\mathrm{NH}_{4}{ }^{+}\right)$through nitrite. Nitrate (also chloride) is considered as very mobile, conservative and often stable (thus persistent) contaminant in groundwater as less adsorbed or retarded in the soil and is thus easily leached by heavy rainfall and infiltrating water [6]. Poor fertilizer application, surface spreading of animal manure, and improper on-site sanitation systems are the greatest sources of high nitrate content in groundwater. Moreover, population density, types of settlements, rainfall recharge rate, sanitation behaviors, and per capita water use highly contribute to nitrate - nitrogen contamination load. Under shallow groundwater and underlain by thin permeable soils and a permeable aquifer, increase in widespread nitrate contamination exists to deteriorate groundwater quality [7].

Using elevated nitrate content in drinking water can commonly cause public health risk and environmental pollution. It acutely causes health effect of methaemoglobinaemia or infantile cyanosis known as "blue baby syndrome", in which blood lacks the ability to carry adequate oxygen to the individual body cells. Infants below three months are at the most risk. In addition, long term exposure (chronological) to excessive nitrate amount has been found in many literatures to be a risk cancers for older people (i.e. gastric, colorectal, bladder, urothelial and brain tumor), esophageal and stomach cancer, diabetes, and thyroid 
hypertrophy $[3,4,8]$. Due to variety of socio-economic impacts associated with nitrate contamination, especially in developing countries, it necessitates to identify and evaluate the nitrate contamination sources and its concentration. Identifying the various sources of nitrate contamination and understanding system dynamics are fundamental to resolve groundwater quality problems and health impacts.

Nitrate contamination in groundwater utilized in western and northwestern coasts of Sri Lanka has extensively experienced for years and highly variable concerning with anthropogenic activities, urbanization and land-use exploitation. For instance, northwestern regions like Kalpitiya, Vanathavillu and Puttalam, the nitrate concentrations have frequently exceeded the permissible level of WHO of $50 \mathrm{mg} / \mathrm{L}$ or $10 \mathrm{mg} / \mathrm{L}$ as nitrate - N. The main causes are due to excessive fertilizer application, dense and improper agricultural practice, and existing on-site sanitations (domestic waste) as widely used in many parts of Sri Lanka [9-12]. Through literatures in western coastal region, on-site sanitations (i.e. soakage, pit latrine, septic tank, etc.) are commonly utilized. The number of pit latrines was estimated about $5-13$ per hectare in the Katana up to Negombo as part of Gampaha district [13]. More than $80 \%$ of Gampaha population uses typical soakage pits constructed with loosely constructed brick walls and bare bottom open to soil for their sewage disposal, while less than $20 \%$ of the population employs septic tanks [14]. This can contribute to higher nitrate and faecal coliform concentration in shallow groundwater, particularly dug wells. Nitrate amount also associates with shallow groundwater table and unconsolidated soil, which enhance nitrate and chloride plume quickly from soil to the water table with slight dispersion.

This study was undertaken in an area as part of Ja-Ela, Katana up to part of Negombo, where productive shallow groundwater exists. The objective of the study aims at identifying and evaluating groundwater nitrate contamination and its potential sources to protect the local public health and the sustainable development through optimizing human activities.

\section{STUDY AREA}

The study area falls within wet zone of Sri Lanka along the western coast in the Gampaha district, extending from Katana to Negombo between latitudes $7^{0} 6^{\prime}-7^{0} 14^{\prime} \mathrm{N}$ and longitudes $79^{0} 51^{\prime}-79^{0} 54.5^{\prime} \mathrm{E}$ with elevation of 0 to $25 \mathrm{~m}$ above mean sea level (amsl). The area receives a high average annual rainfall between 1400 to $2600 \mathrm{~mm}$ with mean annual temperature of $27.8^{\circ} \mathrm{C}$ [15]. The infiltration rate is estimated to be $500 \mathrm{~mm} / \mathrm{a}$. The lateral extent of the area is about 136 $\mathrm{km} 2$. The estimated population of the area is 350,000 with a population density of about 1800 persons $/ \mathrm{km} 2$ (22 persons/ha) and the growth rate of $1.72 \%$. The Katunayake International Airport of the country and the Katunayake Export Processing Zone, fall within the area and both depend on large amount of groundwater. Three main rivers exist in the area flowing from east to west containing Maha Oya in the north and Dandagan Oya and Kalu Oya in the south (Fig. 1). The area is dominated by settlements, coconut lands, homesteads followed by builtup area, paddy field, and water bodies.
The inland area from Katana to Negombo is characterized by sands on a prior old beach plain formation underlain by interbedded clay followed by the crystalline bed rock granite and pink granite. Small portion of laterite is found in the central west close to Negombo lagoon, from Kochchikade through Negombo until Kandana (Negombo-Katunayake Seeduwa - Ja-Ela - Kandana) [16]. Available borehole data from Water Resources Board (WRB) represents that the geological succession of the area composes of regosols and latosols of sands with significant clay (as alluvium soils) about $12-24 \mathrm{~m}$ thick resting on the hard rock. Comparatively lower thickness is found in central eastern parts while deeper thickness in the central, western and southern parts of the area. Additionally, the sand layer thickness seems to have high variation by varying from about $2-20 \mathrm{~m}$ underlain by interbedded clay layer varying from about $5-19 \mathrm{~m}$. The Geological formation of the area has been hydrogeologically categorized as shallow (unconfined) aquifers and moderately deep aquifers (semi-unconfined). The main aquifer consists of sand and sandy clay with thickness ranging from 10 to $15 \mathrm{~m}$, underlain by another aquifer whose thickness ranges between 8 to $15 \mathrm{~m}$ [17]. The unconsolidated sand belt running along the coastal belt particularly from Ja-Ela, to Seeduwa and Katunayake up to Negombo. The water level is estimated to be around $5-8 \mathrm{~m}$ below ground level (bgl) with flow direction from north to south and east to west and then discharge into Negombo lagoon at the west (see Fig. 1).

\section{METHODOLOGY}

\section{A. Water sample collection}

A total of 26 groundwater samples were collected during July to August 2018 from evenly spaced locations of dug and tube wells based on land-uses of the study area. The samples taken were bottled in washed pre-cleaned unfiltered polyethylene (HDPE) containers with inner caps without leaving air space to avoid internal evaporation [18]. It is well noted that the sampling was considered as only one-time sampling. The water from tube wells was sampled after 5minutes purging out to remove any stagnant oxidized water in the well casing. Water parameters examined in this study contained nitrate and chloride concentrations. The contents of nitrate and chloride were analyzed using standard methods, in the Laboratory of Environment Department of Civil Engineering, University of Peradeniya, Sri Lanka. Analytical instrument HACH/DR2010 Spectrophotometer was used to determined nitrate concentrations, while Titration method was operated for analyzing chloride amounts using Potassium Chromate indicator titrated against Silver Nitrate solution. Physical parameters like $\mathrm{pH}$, electrical conductivity (EC) and temperature were measured in the field with sampling time. The recorded information like the observations of the well conditions (i.e. types of well, location, depth, usages) and land-uses was done by using field data sheets.

\section{B. Estimating nitrate amount and contamination sources}

Believed to be a very conservative ion in groundwater, nitrate and chloride contaminants have been chosen as an indicator contaminant for the evaluation nitrate contamination sources. The concentration of both contaminants in groundwater recharge can be semi-quantitatively estimated 
utilizing following empirical method in (1) suggested by ARGOSS [6]; Foster \& Hirata [19].

$$
\mathrm{C}_{\mathrm{N} / \mathrm{Cl}}=\frac{1000 \times \mathrm{a} \times \mathrm{P}_{\mathrm{d}} \times \mathrm{F}}{\left(0.365 \times \mathrm{P}_{\mathrm{d}} \times \mathrm{U}_{\text {non }}\right)+10 \times \mathrm{I}}
$$

Where,

$\mathrm{C}_{\mathrm{N}} / \mathrm{Cl}$ : The concentration of the nitrate or chloride in recharge $[\mathrm{mg} / \mathrm{L}]$

a: Unit weight of nitrogen or chloride in excreta [kg/cap/a]

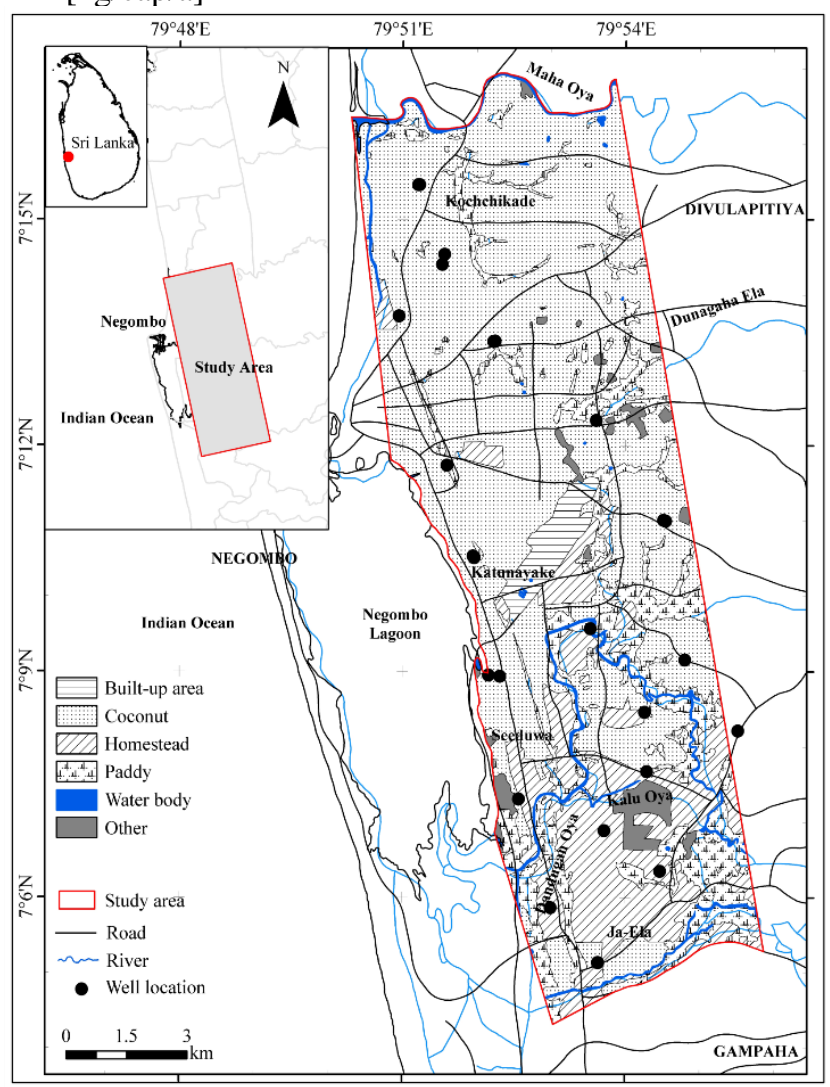

a)
$\mathrm{P}_{\mathrm{d}}$ : Population density [cap/ha]

F: Proportion of excreted nitrogen or chloride leached to groundwater (range $0-1.0$ )

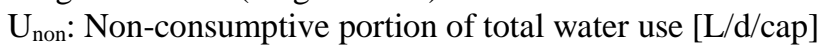

I: Natural infiltration rate [mm/a]

The ratio relationship approach of nitrate to chloride content proposed by Morris et al. [5]; ARGOSS [20] was employed to identify the sources of nitrate in water well at the area whether or not the main source is from feces or agriculture.

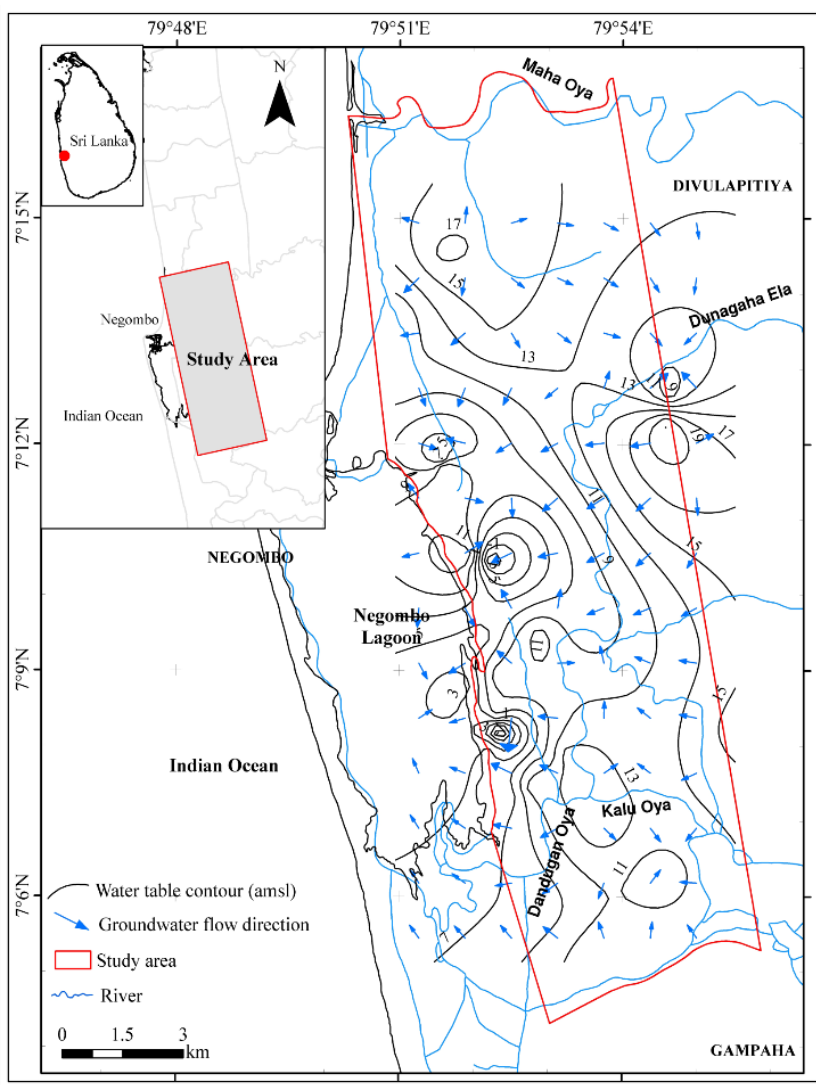

b)

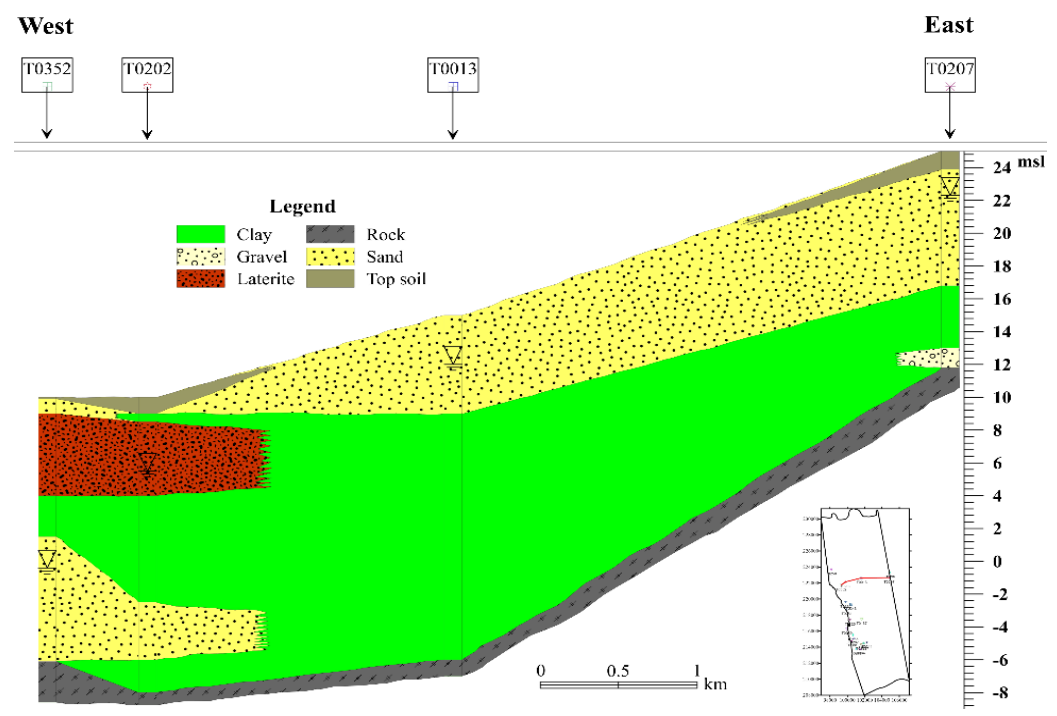

c)

Fig. 1. a) Location of the study area showing land-use categories, b) groundwater table contours and flow directions, and c) east - west cross section of the area.. 


\section{RESULTS AND DISCUSSION}

\section{A. Estimation of nitrate concentration of the area}

The most mobile and stable contaminants are nitrate and chloride, especially from on-site sanitation and agriculture, in form of nitrogen in environments where abundant oxygen is available. A person excretes annual average amount of nitrogen with an estimated value of 4 to $5 \mathrm{~kg}$, and about 2 $\mathrm{kg} / \mathrm{cap} / \mathrm{a}$ for chloride [2,5]. These values respond to (a) parameter used in (1), representing as unit weight of nitrogen in excreta. The proportional nitrogen to be leached to groundwater is related to hydrogeological settings of unsaturated materials (see Table1) with reasonable values from $0.01-0.6(1 \%-60 \%)$. Thin and permeable soil like sand and gravel gives higher percentage of potential leached nitrogen. However, in fractured sediments, possible leached value is up to 1.0 (approximately 100\%) [19 - 22]. All these mentioned leaching fraction is $\mathrm{F}$ parameter in (1), denoting as proportion of excreted nitrogen leached to groundwater.

TABLE 1. PROPORTIONAL PERCENTAGE OF POTENTIAL NITRATE LEACHED FROM ON-SITE SANITATION [20]

\begin{tabular}{|c|c|}
\hline Hydrogeological settings & $\begin{array}{c}\text { Nitrate fraction likely to be } \\
\text { leached }\end{array}$ \\
\hline \multicolumn{2}{|c|}{ 1. Unconsolidated sedimentary aquifer } \\
\hline i) Clay, silt, fine sand & $\begin{array}{c}\text { Up to } 0.3 \text { that could be very low, } \\
\text { particularly shallow water table } \\
\text { and clayey sediments }\end{array}$ \\
\hline ii) Fine - medium sand & Approximately 0.3 \\
\hline iii) Medium sands and gravels & $0.3-0.5$ \\
\hline \multicolumn{2}{|c|}{ 2. Weathered basement aquifer } \\
\hline i) Thick weathered layer & $\begin{array}{c}\text { Up to } 0.3 \text {, yet could be very low } \\
\text { especially where water table is } \\
\text { shallow and weathered material } \\
\text { clayey }\end{array}$ \\
\hline $\begin{array}{c}\text { ii) Thin and/or greatly permeable } \\
\text { weathered layer }\end{array}$ & $0.3-0.5$ \\
\hline $\begin{array}{l}\text { 3. Fractured consolidated sedimentary } \\
\text { aquifer }\end{array}$ & Up to 1.0 \\
\hline
\end{tabular}

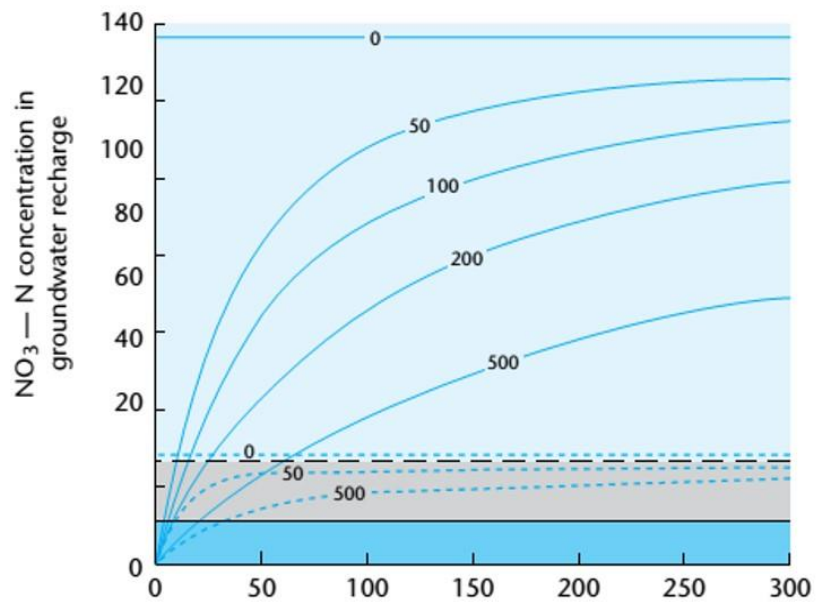

a) variation with $I$ and $u$ population density (persons/ha)
Using known population density and applying the (1) above with similar average amount of non-consumptive water use (Unon) and variation of I and F, the potential amount of nitrate concentration leached from seepage water from in-situ sanitation can be postulated by conducting experimental figuration in Fig. 2. From this figure, the capability of producing troublesome nitrate content from the case of the area is expected greater than $40 \mathrm{mg} / \mathrm{L}$ on high nitrogen leaching condition.

However, in the case of the study area dominated by unsaturated zone materials as medium sand, the reasonable value of leaching fraction thus is supposed to be $0.5(\mathrm{~F}=0.5)$. As a result, the troublesome average nitrate concentration in groundwater in the area should be less than $20 \mathrm{mg} / \mathrm{L}$. This value may be due to less population density and possible dilution from high rainfall of the area. It is well noted that this estimated nitrate is considered as only from sanitary systems.

\section{B. Current status condition of nitrate in water well}

The wells investigated in this study were dug and tube wells which abstract water from unconfined aquifer. The wells in the study site were shallow with a maximum groundwater depth of $15 \mathrm{~m}$ and with majority of about $5 \mathrm{~m}$ bgl. According to WRB borehole dataset and field measurement in 2018, the regional groundwater flow on the study area is from east to west and north to south then discharge to Negombo lagoon in the west (see Fig.1).

It should also be noted that majority of community in the area are relying on shallow dug wells for their everyday lives, which is on most houses, dug wells and on-site sanitation exist. The populous community is particularly found in Ja-Ela in the south and Seeduwa and Katunayake in central southwest and central part, respectively along Negombo lagoon, where are dominated by sandy aquifer. Recently, the 26 analyzed groundwater samples shows that nitrate concentration of the shallow groundwater within the Katana up to Negobmo varies from

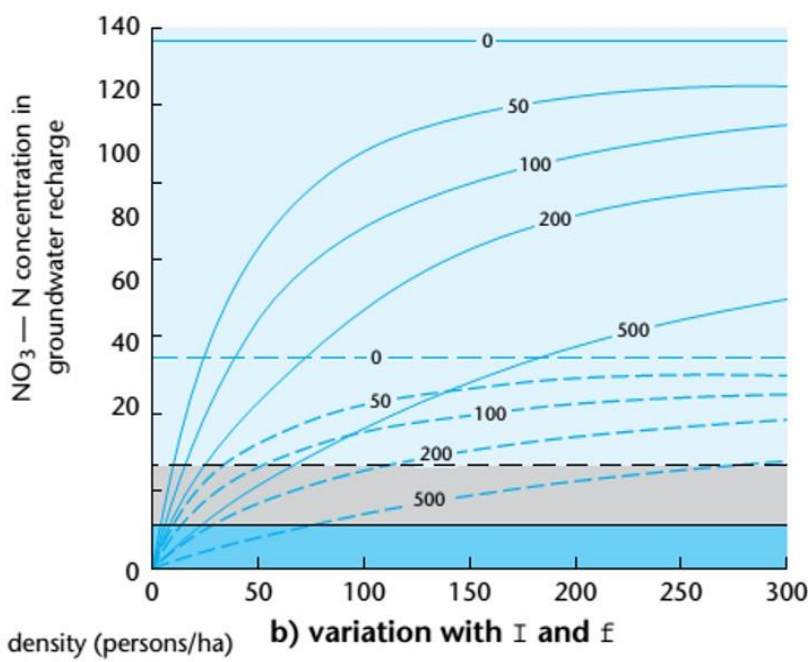

- I $(\mathrm{mm} / \mathrm{a})$ for $\mathrm{f}=0.2 \mathrm{u}=50 \mathrm{l} / \mathrm{d} / \mathrm{cap}$

I $(\mathrm{mm} / \mathrm{a})$ for $\mathrm{f}=0.5 \mathrm{u}=50 \mathrm{l} / \mathrm{d} / \mathrm{cap}$

$\ldots I(\mathrm{~mm} / \mathrm{a}), \mathrm{f}=0.5 \mathrm{u}=250 \mathrm{l} / \mathrm{d} / \mathrm{cap}$

recommended

Fig. 2. Range of proportional nitrate concentration in the area (adopted from Putra [2]; Foster et al. [23]). 
from $2-27.5 \mathrm{mg} / \mathrm{L}$ with mean value of $8.5 \mathrm{mg} / \mathrm{L}$, while the mean chloride in the water well is $4.7 \mathrm{mg} / \mathrm{L}$ ( $\min .0$ and $\max$. 11.7). The $\mathrm{pH}$ values range from 5.6 to 7.8 with an average of 7.1 (see Table 2). The majority of the samples show higher nitrate concentration observed from non - agricultural as human settlements rather than agricultural areas like coconuts, especially located in south, central south and central parts of the area. This indicates that nitrate maybe comes from sewage systems or septic tanks. The further notation shows that the nitrate values from tube wells were lower than that from dug wells.

TABLE 2. PROPORTIONAL PERCENTAGE OF POTENTIAL NITRATE LEACHED FROM ON-SITE SANITATION [20]

\begin{tabular}{|c|c|c|c|c|c|}
\hline Parameter & Min. & Mean & Max. & SD & CV \\
\hline $\mathrm{NO}_{3}{ }^{-}$ & 2 & 8.5 & 27.50 & 7.6 & 89.8 \\
\hline $\mathrm{Cl}^{-}$ & 0 & 4.7 & 11.7 & 3.2 & 67.6 \\
\hline $\mathrm{pH}$ & 4.5 & 6.1 & 7.5 & 0.7 & 11.5 \\
\hline Temperature & 25 & 29 & 35.8 & 1.7 & 5.9 \\
\hline
\end{tabular}

deviation, $C V$-coefficient variation in $\%$

The result also indicates that $31 \%$ of the water samples are above the human affected value of $10 \mathrm{mg} / \mathrm{L} \mathrm{NO}_{3}{ }^{-}$, but there is no samples exceeding $50 \mathrm{mg} / \mathrm{L}$ [24]. In natural condition, $\mathrm{NO}_{3}{ }^{-}$concentrations does not exceed $10 \mathrm{mg} / \mathrm{L}$, so that the beyond $10 \mathrm{mg} / \mathrm{L}$ is an indication of anthropogenic pollution, poor sanitation, possible indiscriminate use of higher fertilizers [3].

Fig. 3 shows a box plots of nitrate concentration in shallow groundwater from different land-use types within the study area. This diagram indicates a good relationship between landuse categories and nitrate contents. The mean nitrate content and the range of nitrate distribution are highest in populous settlements classified as non - agriculture. This may be because of nitrate leached from domestic waste. The generalized linear model (GLM) under Poisson regression processed in $\mathrm{R}$ Studio shows that the non-agriculture $(\beta=0.78)$ is the most significant factor $(\mathrm{P}$-value $=0.000012<0.05)$ influencing nitrate level at $95 \%$ confidence level. The highest median nitrate concentration was $6.6 \mathrm{mg} / \mathrm{L} \mathrm{NO}_{3}{ }^{-}$(min. 2, max. 27.5 ) recorded non - agriculture (with coefficient variation, $\mathrm{CV}$ of $84 \%$ ), whereas lower median concentration was 3.7 $\mathrm{mg} / \mathrm{L} \mathrm{NO}_{3}{ }^{-}$(min. 2.3, max. 12.4) in coconut + paddy cultivation lands (with $\mathrm{CV}$ of $65 \%$ ) and lowest $3.3 \mathrm{mg} / \mathrm{L} \mathrm{NO}_{3}{ }^{-}$ in other areas (free or barren lands). The witness for lower concentration of nitrate in the coconut + paddy lands categorized as agriculture may be due to the low frequency of fertilizer application in this land-use type compared to the settlements supplying human waste (i.e. excreta and urine). Moreover, this current study shows that nitrate has high variation with overall $\mathrm{CV}$ of about $90 \%(10 \%<\mathrm{CV}<100 \%)$ and positive correlation of nitrate with major ions, indicating that groundwater is greatly affected by anthropogenic factors rather than accumulated from the aquifer materials (especially on-site sanitation from dense settlements and also agricultural activities) with additional natural factors like climate and hydrogeological settings [25 - 27].

\section{Nitrate contamination sources}

Land-use is related to the human activities, and not only land-use greatly roles for identifying nitrate concentration in groundwater, but also another possibility, such as intrinsic hydrogeological conditions. As sea water has very low nitrate amount of $<1 \mathrm{mg} / \mathrm{L}$ [28] and no evidence from geological source for nitrate in the area exists, higher nitrate may be mainly contributed from the existing sanitation and waste systems with addition from acts of agriculture.

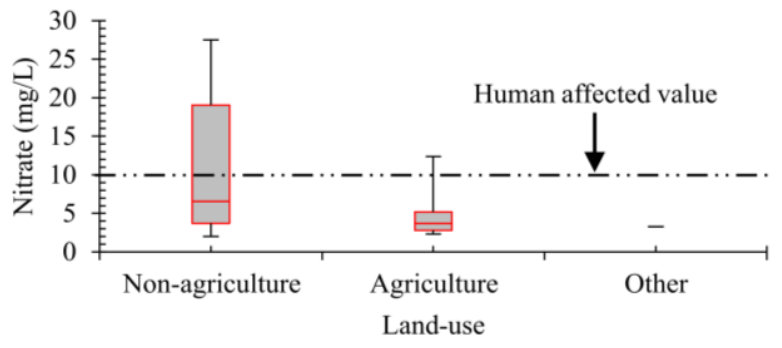

Fig. 3. Box plot showing distribution of nitrate concentrations based on land-uses in the area.

The inference of this can be drawn while the concentration of nitrate in groundwater under similar land-use is actually varied. However, the settlement (housings, septic tanks, sanitation systems, sewage systems, etc.) is the most serious source of producing contaminant like nitrate and chloride to subsurface water, and agriculture becomes as another source. The contaminant loading from the settlements with all their complexities of housing, commercial, and service activities has higher level than any other types of land-use activities, which is following order; urban > sub urban > agriculture > open space (other) [29]. Based on the land-use categories of the study area, the average value of the groundwater nitrate concentration is expressed in this following order; non agriculture $>$ agriculture $>$ other (Fig. $3 \& 4$ ). This can imply that two principle anthropogenic origins of nitrate in the area are from domestic wastewater leakage followed by possible agricultural practice.

For the limitation of this current study, it is obligatory to prove and identify where the groundwater nitrate comes from and whether it originates from on-site sanitation (faecal source) or from agriculture or from both on-site sanitations and possible agricultures. To achieve this, nitrate/chloride ratio originally proposed by Foster \& Hirata [19]; ARGOSS [20] is used for elucidation. This method has later been successfully tested by several authors like Putra [2]; Morris et al. [5]; Putra [29]; Sudarmadji [30]; Fathmawati et al. [31]. Nitrate - chloride was commonly employed as ion maker rather sulfate to identify the groundwater contamination particularly in an improper urbanized area. They are very mobile and conservative elements with little degradation during transport [32-33]. The ratio between nitrate and chloride was not only adopted to predict the source of nitrate contamination in water well, but also to manifest the increase of nitrate concentration in the settlement areas and may help to indicate the origins of the nitrate and the percentage of organic nitrogen, derived from on-site sanitation, that is oxidized and leached to the water table.

The result in the diagram of Fig. 5 reveals that most of the wells investigated in this study demonstrate ratios of nitrate/chloride about 2:1, which falls within 1:1 and 8:1. 
From many experiments, ARGOSS [20] has concluded that where the nitrate/chloride ratio is between $1: 1$ and $8: 1$, then it is likely that the nitrate is primarily from a faecal source.

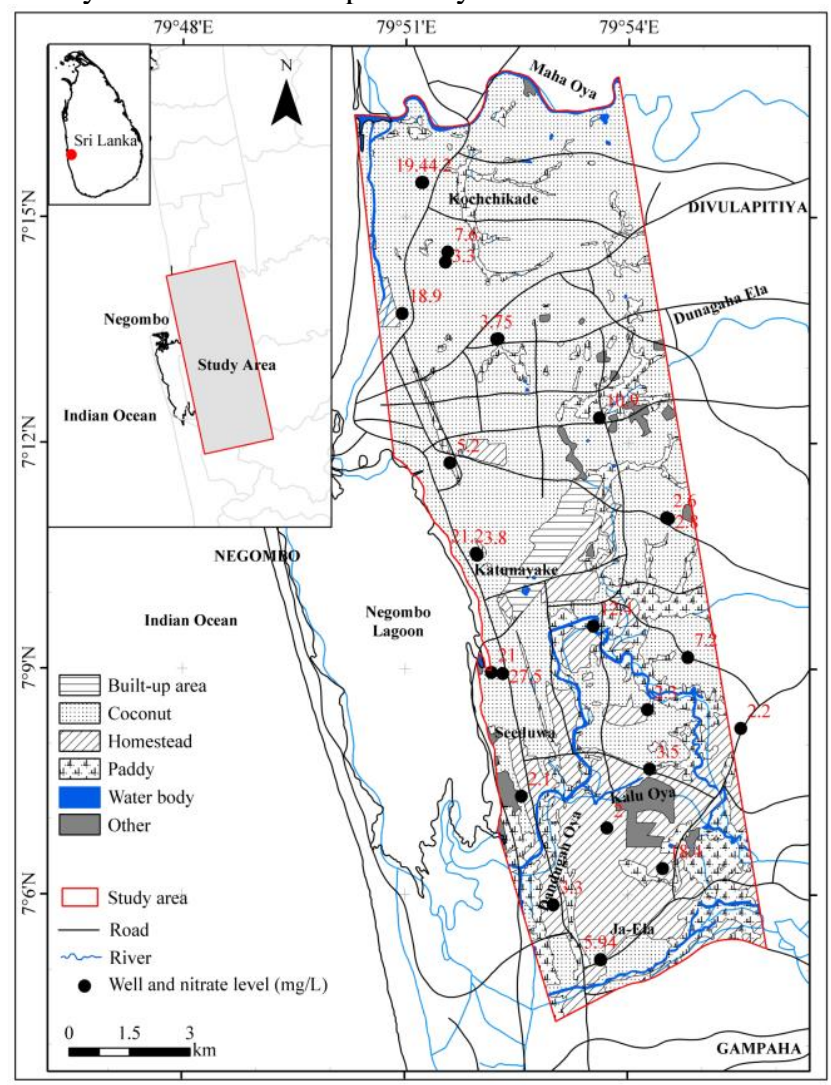

Fig. 4. Composite map of nitrate amount and land-uses within the area.

If the single source of nitrate and chloride is actually from domestic effluents, the ratio of these ions in underlying shallow groundwater should be approximately $2-2.5: 1$ (or the ratio of chloride to nitrogen in human waste is about 1:2). With greater ratios of nitrate:chloride and outside range of $1: 1$ and $8: 1$, the proportional nitrate derived from other factor, non - faecal sources (as inorganic fertilizers) is likely to be higher, even though some may still be derived from faecal matters.

Therefore, the ratio of nitrate/chloride in the study area has proved that the origin of nitrate contamination in water well, on one hand, is from feces. On the other hand, some samples from the land-use setting have the ratio of nitrate/chloride in groundwater out of range $1: 1$ and $8: 1$. This proves that not all nitrogen from on-site sanitation of the area leached to groundwater, but the source may be from agricultures with fertilizer application. However, the assumption validity of the ratio may not exist once another wastewater goes into the disposal systems (e.g., gray water), which consists of additive chloride [5,31]. It should also be noted that some samples taken from shallow groundwater under dense settlements (not so far from the country's airport) surrounded by coconuts along main road close to Negombo lagoon in the west contain high nitrate that is also mainly from faecal source. This evidence may be due to very mobile and stable nitrate moving with groundwater flow in the area from east to west with an estimated hydraulic conductivity $12 \mathrm{~m} /$ day. Thus, the observed groundwater nitrate could reflect the effect of upstream activities. Since the growth of nitrate leaching concerned with the mushrooming of population and urbanization process as well as agricultural acts, Putra [2] inferred that higher percentage of nitrate leaching and concentration occur in old developed area (i.e. older unsewered area) than new developed area.

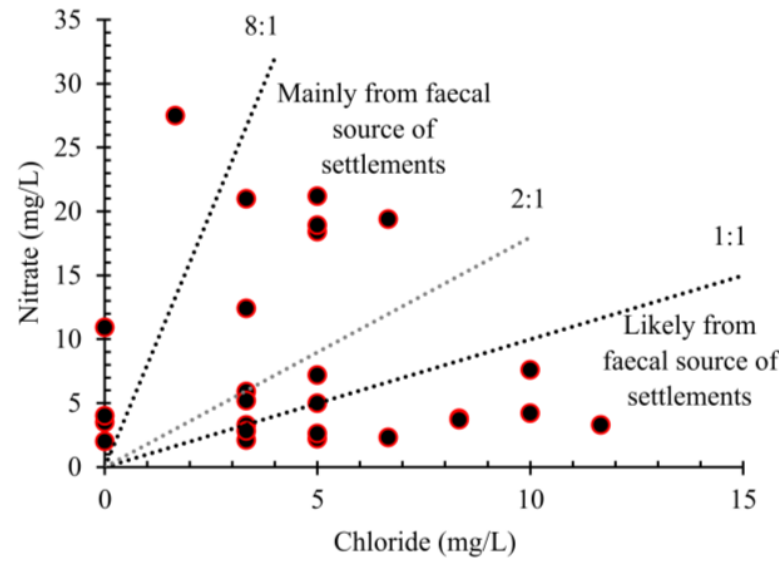

Fig. 5. Diagram showing groundwater nitrate versus chloride concentration of the area (nitrate/chloride ratio).

The assumption of this inference is based on few main phenomena, which include (i) ammonium adsorption capacity of the soil zone may be fully utilized in older systems, (ii) ammonia may be poorly adsorbed as saturated and reducing conditions happen in the soil zone under unsewered sanitations are, and (iii) diminution of denitrification process in aquifer. With rapid shallow groundwater extraction, aerobic condition enhances, and nitrogen will be oxidized to nitrate through nitrite from ammonia, which is call nitrification shown in (2). Nitrification plays as a vital role to produce nitrite $\left(\mathrm{NO}_{2}^{-}\right)$and nitrate $\left(\mathrm{NO}_{3}^{-}\right)$. This process takes place naturally and is carried out in two steps [34], in which the first step is nitrification that uses a type of bacteria called nitrosomonas. During the process of nitrification, $\mathrm{NH}_{3}$ (ammonia) is oxidized into $\mathrm{NO}_{2}^{-}$(nitrogen dioxide).

$$
\mathrm{NH}_{3}+1.5 \mathrm{O}_{2} \rightarrow \mathrm{NO}_{2}^{-}+\mathrm{H}^{+}+\mathrm{H}_{2} \mathrm{O}
$$

The second part is called nitration process, which utilizes the enzyme nitrite oxidoreductase to complete the nitrification process in (3).

$$
\mathrm{NO}_{2}^{-}+0.5 \mathrm{O}_{2} \rightarrow \mathrm{NO}_{3}^{-}
$$

Once these processes are completed, the possible occurrence of nitrate reduction to nitrogen exists through the progressive dilution effect of water percolation, denitrification process and geological conditions, yet it is not effective in water well, hence the nitrate behavior is almost the same as conservative substances. As mentioned earlier, nitrate as stable ion is not easily transformed physically, biologically or chemically in its travel to groundwater [32]. Natural denitrification is also recognized to happen when shallow aquifer environmental redox potentials are less than $300 \mathrm{mV}$, and when heterotrophic bacteria in presence of organic carbon existing. Absence of organic carbon enhances other chemical species such as sulphides and minerals containing ferrous iron $\left(\mathrm{Fe}^{2+}\right)$ to reduce nitrate to nitrogen [35]. This condition causes soil microbes to use $\mathrm{NO}_{3}{ }^{-}$ions as the electron acceptor during 
microbial respiration and leads to a process of reduction in which first $\mathrm{NO}_{3}{ }^{-}$is denitrified as converted to nitrogenous gas and then ferric iron $\left(\mathrm{Fe}^{3+}\right)$ is reduced to ferrous iron, which is serving as indicator of denitrification process [36]. High reducing condition is found in clayed soil due to lower permeability and secondary iron-bearing phases, which control the input of $\mathrm{NO}_{3}{ }^{-}$into groundwater [1,37]. Regarding to the normal $\mathrm{pH}$ range of groundwater $(\mathrm{pH}=5-8)$, dissolved iron will present as $\mathrm{Fe}^{2+}$, since $\mathrm{Fe}^{3+}$ is solid and insoluble under these conditions [33]. This fact is reasonable to state that the denitrification condition in the shallow groundwater system of the study area was more appropriate years ago, resulting low nitrate concentrations in groundwater (see Fig. 4). Even though, recent nitrate concentration is still low, it will continue to rise as increase in population, settlements and anthropogenic activities. As estimated, a population density of the area is about 1800 persons $/ \mathrm{km} 2$ and the growth rate of $1.72 \%$, which is high compared to the country population density of 342 persons $/ \mathrm{km} 2$ with growth rate of $1.1 \%$ (est. 2017). Increase in nitrate trend is evidenced if on-site sanitation and optimization of anthropogenic acts (i.e. fertilizer application) are not properly set up.

Lowered nitrate concentration in water well will not exist if indiscrimination of domestic water disposal, particularly human product widely performs with unsafe distance from water sources. Somehow nitrate in groundwater can be reduce through dilution of percolating water, but effectiveness is not valid if the high nitrate load came from an extensive polluting source within a sizable area [20,31]. Thus, appropriate management and monitoring should be integrated to prevent nitrate exposure danger to water well from contamination sources where drinking water is available for people as well as community. The community is not encouraged to utilize high contaminated nitrate, which can cause negative health impacts. Water containing nitrate cannot be uncovered by tasting (like chloride), and removal by boiling is not commendable way as this will concentrates the nitrate ion in solution. The local government cooperating with local health sector should distribute information related to nitrate risk as periodically monitored by the local health center via the health center of community. Additionally, training and announcement should be broadly publicized, especially for uneducated people as well as for famers. Nitrate risks can be mitigated through several following possible techniques [34].

- Sewage system management (i.e., be treated before discharged, install environmentally sound sewage facilities, respect effluent disposal guideline, train and educate local administration, formulate awareness campaigns for the general public)

- Environmental protection policies and regulations (i.e., governmental policy measures like Nitrate Directive, Water Framework Directive, Groundwater Directive, etc.)

- Drinking water standards (i.e., WHO and EPA guidelines)

- Prevention method (i.e., limit the amount of nitrogen applied, avoid over-irrigation, etc.)

- Beneficial management practices (BMP) for agriculture (i.e., use nitrogen fertilizer as efficiently as possible via better timing and placement, remove key sources of nitrogen)

- Prevention techniques (i.e., building manure storage in concrete pits, install a slurry-store)

- Water treatment techniques (i.e., blending drinking water, ion exchange, reverse osmosis, biological denitrification, in-situ treatment)

\section{CONCLUSIONS}

The study revealed that the contamination of nitrate in the study area is concerned with land-uses and anthropogenic acts. The source of nitrate contamination in shallow groundwater in the Katana up to Negombo can be inferred to derive from onsite sanitations under denser population, which is followed by agriculture as secondary significance. The evidence from ratio of nitrate/chloride $(1: 1-8: 1)$ also suggested that the primary nitrate contamination in water wells in the study area is of faecal origin due to improper on-site sanitations, while the rest may be from fertilizer applications. The estimated nitrate concentration in the area through application of equation suggested by Foster \& Hirata [19] demonstrates a rough range of values as approximately less than $20 \mathrm{mg} / \mathrm{L}$. Nonetheless, its usefulness is for predicting the probable nitrate content in groundwater under on-site sanitations. Recently, the analyzed groundwater samples indicated that $31 \%$ of the water samples are above the human affected value of $10 \mathrm{mg} / \mathrm{L} \mathrm{NO}_{3}{ }^{-}$though there are no samples exceeding $50 \mathrm{mg} / \mathrm{L}$. Lower nitrate in the area may be due to denitrification processes. Although, the current condition of nitrate in the area is still found to be low, it will possibly increase if no proper management action to face with population growth rate and no on-site sanitations are adequately and properly established. Although this study has limited information, it may be considered as a good starting point and background value for identifying groundwater quality deterioration by nitrate.

\section{ACKNOWLEDGMENT}

NORAD WaSo Asia Project is highly acknowledged for the financial assistance.

\section{REFERENCES}

[1] P. Jayasingha, A. Pitawala, and H.A. Dharmagunawardhane, "Vulnerability of coastal aquifers due to nutrient pollution from agriculture: Kalpitiya, Sri Lanka," Article of water, air, soil, pollution, 2011. Doi: 10.1007/s11270-010-0728-y.

[2] D.P.E. Putra, "Estimation, reality and trend of groundwater nitrate concentration under unsewered area of Yogyakarta City - Indonesia," J. SE Asian Appl. Geol., Vol. 2, issue 1, pp. 20-27, Jan-Apr 2010.

[3] WHO, Guideline for Drinking Water Quality, $4^{\text {th }}$ ed., Geneva, World Health Organization, 2011, 541p. ISBN 9789241548151.

[4] G.D. Smith, R. Wetselaar, J.J. Fox, R.H.M. van de Graaff,, D Moeljohardjo, J. Sarwono, S.R.A. Wiranto, T. Suharto, and Basuki, "The origin and distribution of nitrate in groundwater from village wells in Kotagede, Yogyakarta, Indonesia,” Hydrogeology Journal, vol. 7, pp. 576-689, 1999.

[5] B.L. Morris, A.R.L. Lawrence, P.J.C. Chilton, B. Adams, R.C. Calow, and B.A. Klinck, Groundwater and its Susceptibility to Degradation: A Global Assessment of the Problem and Options for Management. Early Warning and Assessment Report Series, RS. 03-3. Nairobi, Kenya: United Nations Environment Programme, UNEP, 2003.

[6] ARGOSS, Assessing Risk to Groundwater from On-site Sanitation: Scientific Review and Case Studies. British Geological Survey Commissioned Report, CR/02/079N, 2002, 4411pp. BGS Keyworth, England. 
[7] L.W. Sinton, "A Groundwater Quality Survey of an Unsewered Semi rural Area, New Zealand," Journal of Marine and Freshwater Research, vol. 16, pp. 317-326, 1982.

[8] P.W.L. Clough, "Nitrates and Gastric Carcinogenesis," Environmental Geochemistry and Health, vol. 2, issue 3, pp. 91-95, 1983

[9] A.R. Lawrence, P.J. Chilton, and D.S.O. Kuruppuarachchi, "Review of the Pollution threat to Groundwater in Sri Lanka," Journal of Geological Society of Sri Lanka, vol. 1, pp. 85-92, 1988.

[10] D.S.P. Kuruppuarachchi and W.A.R.N. Fernando, "Impact of Agriculture on Groundwater Quality: Leaching of Fertilizers to Groundwater in Kalpitiya Peninsula,” J. Soil Sci. Soc. Sri Lanka, vol. 11, pp. 9-16, 1999.

[11] K.M.S.M. Kumarasinghe, J. Gunatilake, A.S.M.N.B. Samarakoon, R.R.G.R. Rajapakshe, and K.K.S.A. Withanage, "Groundwater Vulnerability and Hydrogeological Setup in Shallow Aquifer in Kalpitiya Peninsula," Water Resources Research in Sri Lanka. Symposium proceedings of the Water Professionals' Day, At University of Peradeniya, Peradeniya, 2016.

[12] P. Ratha, K.D.W. Nandalal, H.M.T.G.A. Pitawala, H.A. Dharmagunawardhane, and S.B. Weerakoon, "Groundwater Vulnerability: A Status Review on North Western Coastal Aquifers of Sri Lanka, Based on a GIS - DRASTIC Assessment. Symposium Proceedings of Sixth International Symposium on Water Quality and Human Health: Challenges Ahead, PGIS, Peradeniya, Sri Lanka, 13-14 July 2018.

[13] S. Barthiban, B.J. Lloyd, and M. Maier, "Applicability of a Surveillance methodology for the Microbiological Safety of Well Water Supplies, in a Highly Vulnerable Hydrogeological Setting - A Case Study Based Findings from the West Coastal Area of Sri Lanka," Journal of Water Resource and Protection, vol. 4, issue 2, pp. 899-912, 2012.

[14] H.M.K.S. Bandara, and M.M.M. Najim, "Compliance with Standards and Immerging Issues of Household Sewage Disposal Systems in Gampaha Municipality Area in Western Sri Lanka," Journal of Environmental Professionals Sri Lanka, vol. 2 issue 2, pp. 1-12, 2013.

[15] Department of Census and Statistics, Statistical Abstract 2016: Population. Available http://www.statistics.gov.lk/Abstract2016/index.asp?page=chap2, [accessed 04 August 2017], 2012.

[16] C.R. Panabokke, Groundwater Conditions in Sri Lanka. A Geomorphic Perspective. 47/5, Maitland Place, Colombo 7, Sri Lanka: National Science Foundation of Sri Lanka, 2007, ISBN: 978-955-590-079-9.

[17] E.R.N. Gunawardena and P.K.D. Pabasara, "A framework for groundwater policy for Sri Lanka. Symposium proceedings of groundwater availability and use in the dry zone of Sri Lanka," CapNet Lanka, PGIA, Peradeniya, Sri Lanka, 2016.

[18] APHA, Standard Methods for the Examination of Water and Wastewater (SMWW), 20 $0^{\text {th }}$ Ed., American Public Health Association/American Water Works Association/Water Environment Federation, Washington DC, 1999.

[19] S.S.D. Foster and R.C.A. Hirata, Groundwater Pollution Risk Assessment: A Methodology Using Available Data. WHO-PAHOCEPIS Technical Report (Lima-Peru), 1988, 87pp.

[20] ARGOSS, Guidelines for Assessing the Risk to Groundwater from Onsite Sanitation, British Geological Survey Commissioned Report, CR/01/142, 2001, 97pp.

[21] GWMAP, Groundwater Quality Under Three Unsewered Subdivisions in Minnesota, Minnesota Pollution Control Agency, Groundwater and Toxics Monitoring Unit, Environmental Monitoring and Analysis Section, Environmental Outcomes Division, Minnesota, 2000.
[22] D.R. Gajurel, Z. Li, and R. Otterpohl, "Investigation of the Effectiveness of Source Control Sanitation Concepts Including Pretreatment with Rottebehaelter," Water Science and Technology, vol. 48 , issue 1, pp. 111-118, 2003.

[23] S. Foster, R. Hirata, D. Gomes, M. D'Elia, and M. Paris, Groundwater Quality Protection: A Guide for Water Utilities, Municipal Authorities, and Environment Agencies. Washington, D.C.: The International Bank for Reconstruction and Development/The World Bank, 2002.

[24] SLS 614, Specification for Potable Water Physical and Chemical Requirements, $1^{\text {st }}$ revision, Sri Lankan Standards Institution for Potable Water.

Available http://www.slsi.lk/web/index.php?option=com_slstandards, [accessed December 30, 2017], 2013.

[25] J.P. Jayasingha, H.A. Dharmagunawardhaneand, and A. Pitawala, "Geochemistry of Quaternary Aquifers of Sri Lanka: A Study from Northwestern Coastal Area," Proceedings of the Peradeniya University Research Sessions, Sri Lanka, vol. 14, pp. 353-355, $3^{\text {rd }}$ December, 2009.

[26] Q. Zheng, T. Ma, Y. Wanga, Y. Yan, L. Liu, and L. Liu, "Hydrochemical Characteristics and Quality Assessment of Shallow Groundwater in Xincai River Basin, Northern China," Procedia Earth and Planetary Science, vol. 17, pp. 368 - 371, 2017.

27] P. Ratha, K.D.W. Nandalal, H.M.T.G.A. Pitawala, H.A. Dharmagunawardhane, and S.B. Weerakoon, "Hydro-geochemical Appraisal to Promote Groundwater Sustainability at Kalpitiya area, North-western Coastal Aquifer, Sri Lanka," Proceedings of the 9th International Conference on Sustainable Built Environment, Kandy, Sri Lanka, 13-15 December 2018

[28] J.D. Hem, Study and Interpretation of the Chemical Characteristics of Natural Water, $3^{\text {rd }}$ Ed. US Geol Surv Water-Supply Pap 2254, 1989, 263pp.

[29] D.P.E. Putra, The Impact of Urbanization on Groundwater Quality: A Case Study in Yogyakarta City-Indonesia. PhD Thesis. University RWTH Aachen, Germany, 2007, 166pp.

[30] Sudarmadji [Geographical Agitation of Unconfined Aquifer Chemistry in Yogyakarta Municipality] Agihan Geografi Sifat Kimiawi Airtanah Bebas di Kotamadya Yogyakarta. Universitas Gadjah Mada, 1991.

[31] F. Fathmawati, F. Jajah, H.S. Adi, and P.E.P. Doni, "Origin an Distribution of Nitrate in Water Well of Settlement Areas in Yogyakarta, Indonesia,” Environ Monit Assess 190: 628, 2018. Doi: https://doi.org/10.1007/s10661-018-6958-y.

[32] R.A. Freeze and J.A. Cherry, Groundwater. Prentice-Hall. Inc. Englewood Cliffs, N.J. 07632, 1979, 604 p., ISBN: 0-13-365312-9.

[33] C.A.J. Appelo and D. Postma, Geochemistry, Groundwater and Pollution, $2^{\text {nd }}$ Edition. Amsterdam, the Netherlands, 2005, 634p., ISBN 0415364213 .

[34] A. Zhou, A Global Assessment of Nitrate Contamination in Groundwater. Internship report. IGRAC, 2015, 27pp.

[35] S. Appleyard, "The Impact of Urban Development on Recharge and Groundwater Quality in Coastal Aquifer near Perth, Western Australia," Hydrogeology Journal, vol. 3, issue 2, pp. 65-75, 1995.

[36] P.F. Vendrell, P.B. Bush, R. Hitchcock, W.C.Jr. Johnson, D.E. Kissel, W.I. Segars, and K.B. McSwath, "A Relationship between Nitrate and Iron in Georgia's Groundwater,". K.J. Hatcher (Ed.). Proceedings of the 2001 Geogia Water Resources Conference, the University of Georgia, March 26-27, 2001, pp. 590-593. Athens: Institute of Ecology, The University of Georgia

[37] S. Young, A. Pitwala, and J. Gunathilaka, "Fate of Phosphate and Nitrate in Waters of an Intensive Agricultural Area in the Dry Zone of Sri Lanka," Paddy and Water Environment, vol. 8, issue 1, pp. 71-79, 2010. 